\title{
Reframing migrant identities: Namelessness and impersonation in Dinaw Mengestu's All Our Names
}

Author:

Nick M. Tembo ${ }^{1,2}$ (D)

\section{Affiliations:}

${ }^{1}$ Department of English,

University of Malawi,

Zomba, Malawi

${ }^{2}$ Department of Literary Studies in English, Rhodes University, Grahamstown, South Africa

Corresponding author:

Nick Tembo,

ntembo@cc.ac.mw

Dates:

Received: 22 Dec. 2018

Accepted: 09 May 2019

Published: 19 Aug. 2019

How to cite this article: Tembo, N.M., 2019,

'Reframing migrant identities: Namelessness and impersonation in Dinaw Mengestu's All Our Names', Literator 40(1), a1581. https://doi.org/10.4102/lit. v40i1.1581

Copyright:

C 2019. The Authors. Licensee: AOSIS. This work is licensed under the Creative Commons Attribution License.
Drawing on Jacques Derrida's rationality about the decentring force of language and texts, postcolonial theorist Homi Bhabha uses Derrida's notion of dissemination as a telling metaphor for transcending the idea of boundaries. Bhabha avers that dissemination is 'that moment of the scattering of the people that in other times and other places, in the nations of others, becomes a time of gathering'. His application of the notion of dissemination entails challenging notions of borders and historicity located in the idea of national identity. In this article, I explore the numerous ways in which dissemination is presented as a site for re-examination, refashioning and reinvention of the identity of the African protagonist in Dinaw Mengestu's All Our Names. I critically analyse the sojourner conceit in the novel in the light of impersonation as a narrative technique that the author employs to exemplify how the trope of namelessness reflects and inscribes notions of nomadic and migrant identities. This theme is evident in the anguish and trauma of the dislocated subject's search for belonging and for a sense of selfworth. This anguish is deepened by the racial fault lines that are also inscribed in the novel. I demonstrate that the problem of race performs a difficult task in the narrative, helping to expose 'some of the ways in which the African other is excluded from dominant discourse and rendered invisible through the racially demarcated topography' when he is away from his natal home.

Keywords: Dissemination; sojourner conceit; nomadic lives; namelessness; impersonation; reinvention of identity; racial fault lines.

\section{Introduction}

Drawing on Jacques Derrida's rationality about the decentring force of language and texts, Homi Bhabha uses Derrida's notion of dissemination as a telling metaphor for transcending the idea of boundaries. Bhabha avers that dissemination is 'that moment of the scattering of the people that in other times and other places, in the nations of others, becomes a time of gathering' ([1994]2004:199). Bhabha's application of the notion of dissemination entails challenging notions of borders and historicity located in the idea of national identity. In this article, I explore the numerous ways in which Bhabha's notion of 'dissemination' is presented as a site for re-examination, refashioning and reinvention of migrant lives.

To demonstrate the plural, differential, discursive and double nature of identity associated with migrants, I analyse Ethiopian-American Dinaw Mengestu's All Our Names. Published in 2014, the novel reinvigorates the author's concern with a series of displacements experienced by immigrants and refugees as they reconcile with their in-between states of being. In keeping with the critical examination of migrant identities, the novel employs a split narrative technique in which two narrators - a black man simply known as ' $D_{-}$' (p. 253) ${ }^{1}$ and a sheltered American social worker called Helen - drive the plot of the novel in alternating chapters. The chapters in which the unnamed black narrator is the protagonist are set in Africa, while those narrated by Helen are set in the American Midwest. The story begins in Ethiopia where the black protagonist-narrator is told by his father to leave the country after rumours of soldiers revolting in the south of the country and of university students going into the countryside to persuade youths to join the revolutionary movement reach them. En route to Uganda, the black narrator gives up all the 13 names he was given at birth - which we are never told - just as the bus he boards crosses into Uganda, so that he has no name by the time he arrives in Kampala. His unnameability as he enters Uganda clearly captures the minimisation of the migrant and symbolises that he is a

The closest we come to knowing the black narrator's full and real name is through what he tells an unnamed man who comes to take him away from danger. As he relates: 'I told the man who escorted me to the village my real name, the one given to me at birth. Both he and his son laughed when they tried to pronounce it ... By the time we arrived at the clearing, my name had been transformed into Daniel - a Biblically familiar name among the devoutly Christian people who lived there' (p. 213). Beyond this, we never learn what the actual name is. 
person that is barely recognised by his hosts. I revert to this narrative technique later in this article.

In part then, All Our Names reveals the interesting character of a displaced Ethiopian who travels to Uganda, claiming to be in the country for 'the second-most important conference' (p. 143), having missed out on the first historic writers' conference that had taken place 'a decade earlier' (p. 4). ${ }^{2}$ Nothing much is said about the writers' conference, or whether the narrator participates in it, apart from the fact that he later admits to coming for the writers' conference only for him to be caught up in revolutionary violence. Before long, the black narrator finds himself on the precincts of an unnamed university campus in Kampala, probably Makerere, where he attracts the attention of another poseur in Isaac Mabira. The latter is involved in revolutionary activities aimed at discrediting the government for not doing enough for the poor masses. But then, the revolution - led by a British-educated returnee only known as Joseph - is foiled as government authorities clamp down on the revolutionaries. In the end, Joseph is shot dead by his own soldiers, after which Isaac hands the black narrator a Kenyan passport with no picture in it, a plane ticket and a visa. The black narrator uses these documents to leave Africa, adding that he 'became Isaac as soon as [he] stepped on the plane' to America (p. 175). Taking the black narrator's thoughts here, I see the nature of the travel documents as signalling particular nodes of identity which offer important insights into Mengestu's fictive concerns and the ways in which migrants always negotiate their identities among their hosts. These are some of the issues I flesh out in this article.

To a large extent, the black narrator's journeys and pathways across parts of East Africa and, later, the American Midwest mirror the identity of the author. Mengestu is a postcolonial migrant intellectual living in the West. He was born in Ethiopia in 1978, but his family migrated to the United States when he was only 2 years old. He grew up in Peoria, Illinois, and has spent most of his life there. This doubling (between the author and his black narrator) opens the text to a kind of interpretation where Mengestu could be said to use what Marianne Hirsch calls 'postmemory' to narrate his experience as an immigrant living in the West. Hirsch sees 'postmemory' as the sort of memory that comes in as a consequence of loss. Her observations are in relation to the experiences of secondgeneration holocaust survivors who have over the years developed a new form of remembering past traumatic events initially experienced by their parents and grandparents. As she reminds us:

Postmemory characterizes the experience of those who grow up dominated by narratives that preceded their birth, whose own belated stories are displaced by the stories of the previous generation, shaped by traumatic events that can be neither fully understood nor re-created. (Hirsch 1996:662)

2.Mengestu is most likely referring to the June 1962 African Writers of English Expression Conference, held at Makerere University Kampala In the black narrator's lowing description of this con glowing description of this conference, "a decade earlier, there had been an important gathering of African writers and scholars at the university ... That conce solely of leaving [Ethiopia]. I knew afterward where to go and what I wanted to be: a famous writer, surrounded by like-minded men in the heart of what had to be the continent's greatest city' (p. 4).
Hirsch is of the view that postmemory is mostly relived by children of survivors 'through an imaginative investment and creation' (1996:662) of fictive characters. These 'children' create 'an aesthetics of postmemory', understood to be 'a diasporic aesthetics of temporal and spatial exile that needs simultaneously to rebuild and to mourn' the loss (1996:664). In the narrative context of Mengestu's fiction, the 'postmemory' that inspires his writing is the totalitarian rule that was instituted by the Provisional Military Administrative Council or Derg which led to many Ethiopians leaving the country, including Mengestu's parents. Led by Mengistu Haile-Mariam, the Derg promised to end the misery allegedly caused by the monarchy of Emperor Haile Selassie, only for the new regime to commit the very atrocities it deplored the former regime for. Dislocated from his natal home by the Derg, it can be said that Mengestu is faced with the difficulties of negotiating his identity in the present. He thus uses his own experiences to write the anxieties of people whose experiences are similar to his own. This article then seeks to bring out the nebulous if not deceptive notions of home and belonging in immigrant identities as imagined in the novel.

\section{The trope of namelessness in All Our Names}

While critics today would likely concur that namelessness is the artistic zeitgeist in most migrant narratives, they would probably not assent to the claim that there is a close affinity between migrants and the sort of names they acquire as they work to rebuild and reinvent their identities. Indeed, an interesting parallel can be drawn between namelessness and migrant lives. Names and naming signify belonging and referentiality, just as change of name suggests loss or a shift in one's identity. In Walter Herrscher's (1986:126) reasoning:

$[A]$ person or a phenomenon enters into being and into existence through referential designation because 'without a name, a person or a thing barely exists, it becomes part of our consciousness only when it has a name.

In the context of All Our Names, namelessness is an enduring narrative technique that Mengestu employs to inscribe and exemplify the lives of nomadic and migrant identities.

In 'The Rise of the Nameless Narrator', Sam Sacks (2015) notes that in recent times writers have succumbed to an epidemic of namelessness by not naming their creations. In arguing his idea, he points to what he sees as the ambivalent feeling that most people have about notions of home and belonging. Noting the relative lack of what he calls the realness of [human] existence' ('The Rise'), Sacks holds that the practice of namelessness among most writers is their way of trying to make sense of immigrant lives. In his view, 'namelessness has become an increasingly familiar trait in the fiction of exile, in which immigrants acquire new titles to suit new lives' ('The Rise'). In Sacks's opinion, the stories mediated in this type of fiction are invariably 'about statelessness as a state of being [where] because the narrator has no proper home, he can also have no proper name'. 
His insights provide a useful entry in framing the connection between names or namelessness and migrant identities, and in teasing out whether names can be linked to place or belonging, or lack thereof. The implication here is that being uprooted from a place trumps all identities and notions of belonging.

As a narrative technique then, namelessness provides an important filter through which we can reconstruct the black narrator's exilic emplacement in All Our Names. In many ways, his characterisation as a nameless figure and his wanderings across parts of eastern Africa and the American Midwest are Mengestu's way of making sense of experiences of loss and the 'new' forms of identity immigrants tend to forge for themselves in the wake of that loss. Elsewhere, Mengestu reiterates this point:

We often think that the immigrant story is unique to people who have left their homes. But for me it has increasingly become a story of people who have lost something essential to who they are and have to reinvent themselves and decide who they are in the wake of that loss. How do they find someone to love again? How do they find another home? How is this tied to the experience of violence? How does it reshape our sense of identity and how do we come to terms with it? (Paulick 2014:n.d.)

This emphasis on loss, isolation and a refashioning of one's identity because one is away from his natal home is central to Mengestu's creative writing and numerous discussions on migrant life. The beautiful things that heaven bears, his first novel, is described as an immigrant novel as the author draws on immigrant experiences of Africans in the United States. Sepha Stephanos, the main character in The beautiful things that heaven bears, has fled his home country because of political persecution. The Ethiopia that Stephanos left behind is described in the novel as full of 'hell every day with only glimpses of heaven in between' (Mengestu 2007:99). The assumption that Stephanos makes here is that the United States is better than Africa. Yet, as Aliki Varvogli notes, 'the immigrant does not find paradise in America' because of the racial issues that daily confront him (2012:121). Thus, it could be said that the novel explores themes of loss and the possibility of finding a home. How to Read the Air, his second novel, nods back to the themes of his previous book in that the two alternating stories weaved into the novel that of Jonas Woldemariam as an alienated African living in the United States and that of his Ethiopian parents' early years in the United States - explore the challenges immigrants face as they attempt to integrate. These challenges, again, are laced with racial fault lines. For example, Jonas is constantly asked to explain himself where he really comes from even when he tells his interlocutors that he is from Illinois (the assumption being that he cannot belong to America, given his skin colour and his African name). His parents, too, are seen constantly taking road trips, which nods to their inability to settle in one place for so long because they do not really belong to that place. I thus read Mengestu's writing as participating in the reframing of what I call migrant identities, in so far as it weaves together and validates fragments of lives lived on the social interstices.

As noted earlier, the black narrator drops and 'accepts' names as he wanders from place to place. As well as ' $\mathrm{D}$ ', he is named Professor, Langston, Ali and Daniel to his Ugandan hosts and friends. Later, he is called 'Isaac' to his American friends. This is besides the 13 unmentioned names that his parents had given him at birth back in Ethiopia. This name changing and 'acceptance' is not something to be lamented, Mengestu admits elsewhere, because the nature of the characters in the novel are 'the sort of scattered wreck' that adapt to new environments by, among other things, 'shifting their names, taking on new names' and being forced to abandon the names that they were born with because:

$[W]$ ith each new change, with each new upheaval, they are forced to reconsider exactly who they are. They are [also] forced to reexamine their relationships as not just sort of solid, stable things, but as things that are very much fractured by the politics in which they live in. (Brown 2014:n.d.).

Mengestu, here, focuses on the disguises of character and identity that names, especially those associated with migrants, have. This disguise is foreboded in the novel through the black narrator's father who, we learn, used to call the black narrator a bird when he was a child because the older man thought his son 'lived high in the sky, far above everyone else' (p. 179). The bird imagery that the father uses is instrumental in creating the trope of not belonging we see later in the novel. At one level, the image of the bird soaring into the skies represents the freedom the narrator longs for when he wants to leave his home village for a (seemingly) better life elsewhere. At another level, the bird motif is a foretelling of the wandering the narrator assumes, a foreshadowing of 'statelessness as a state of being' that Sacks associates with contemporary literature of migration ('The Rise'). In a few instances in the novel, the black narrator acknowledges, and even enjoys, this attribute. The first instance occurs when an equally nameless man shows up to whisk him away to 'someplace safe' (p. 211) in a village to the west of Uganda because his bosom friend, Isaac Mabira, thinks he should not be caught up in the revolutionary violence. In reference to the way his hosts' children sing his name, the black narrator thinks that their voices 'were a reminder of [his] place as a curious stranger not totally welcome, but easily tolerated' (p. 219). Elsewhere, he regards himself not just as an interloper, but also as someone whose 'life story consisted of standing on the sidelines' (p. 139). In view of my reading of the black narrator as someone who lives under the shadow of past civil strife, these words and expressions evoke the refugee claim process, wherein those who are on the move are often seen as bystanders, unable to assert any form of identity or belonging to a place. That the black narrator's passport originally had no picture in it and his visa does not allow him to stay in the United States for more than a year is also symbolic. It extends the notion that, as a sojourner, he is neither expected to have any one identity nor to stay in one 
place for too long. It is only fitting, then, that the bird nickname that his father had given him at birth should be a symbol of a drifter who is able to stay on the move.

This narrative voice of the novel helps to create a cynical distance between the protagonists and those they come in contact with. For instance, the black narrator regards himself as enjoying 'a privileged perch' with the people of western Uganda, just as he begins to understand why his father had called him bird when he was a child (p. 219). Given my interest in the workings of the novel as a text that advances namelessness as a new form of identity for migrants, the expression 'privileged perch' becomes an interpretive device for understanding what Giles Foden describes as 'the shifts and residues of lives in flux' (Foden 2014:n.p.). As such, I suggest a troubled, more disruptive, reading of the bird's-eye view metaphor in the novel as symbolising the spatial and temporal distance that is created between migrant lives and the host society, as if to tell us that their identity is (literarily and literally) tangential, like that of a bird that perches from one branch to the next in its continued search for a final landing. The implication here is that far from being an ordinary panoptic aerial view, the 'perch' brings with it the notion of temporary belonging to a place, which is what the life of the black protagonist is in the novel. The question remains: what does this temporal perch - read as Mengestu's construction of his lived experiences in America through the eyes of the black protagonist - tell us about the angst of migrant identities in the host community? In the next section, I explore how this angst is further inflected in All Our Names.

\section{The immigrant experience in America}

In its exploration of the conflicted identities of exilic and/or migrant lives, this article is further framed by a concern with the kind of 'reception' migrants get when they leave their natal homes. To this end, the rest of the article deals with what Mengestu has elsewhere called 'the problem of race that continue[s] to persist and linger' in our societies (Brown 2014:n.d.) as one of the ideological frameworks that reinscribe the novel, and which forms part of the immigrant experience in America.

After escaping from 'violent' Africa, 'Isaac' moves to Laurel, a quiet, semi-rural town in America's Midwest. Here, he meets and starts a romantic relationship with Helen, a sheltered white social worker assigned by the Lutheran Relief Services to help him acclimatise to his new life. Although there is no doubt that this is a story of love at first sight, the social consequences of their relationship soon become apparent: Laurel may have 'stopped segregating its public bathrooms, buses, schools, and restaurants' only a decade earlier, but it 'still [doesn't] look too kindly upon seeing its races mix' (p. 17). Here, the novel raises questions about the (African) immigrant's coming to terms with the disillusionment of the American dream. Its primary import lies in its ability to highlight the shifting sense of identity of migrants in America. Perhaps this is what leads Varvogli to say that Mengestu's fiction is concerned with articulating 'some of the ways in which the African other is excluded from dominant discourse and rendered invisible through the racially demarcated topography' (2012:120) in America's Midwest.

We get further confirmation of racial stratification and systemic racism in the novel from Helen, who speaks of the open hostility she and 'Isaac' meet when they go out for a meal at a local restaurant: 'the entire diner fell silent as soon as we entered. All eyes turned towards us' (p. 36). But this is only the beginning of the resistance from the restaurant's white patrons. When the two take their seats and place their orders, the waitress assigned to them comes back, empty handed, and asks if they would like to have takeaways, a request that they politely decline (p. 37). In a last-ditch effort to make them leave, they are served their meals differently. Helen's lunch is served 'on the standard cream-colored plates used for everyone' in the restaurant, while 'Isaac's' is served 'on a stack of thin paper plates barely large enough to hold the food [with] a plastic fork and knife ... wrapped in a napkin ... placed on top' (p. 39). Further evidence of colour bar is reflected in yet another restaurant scene in the novel. After driving for some time, the two decide to branch off for lunch. But the reception they receive from the white patrons is chilly. As Helen relates:

What we didn't have ... were many places where Isaac and I could publicly rest without fear of who was watching us. When we stopped for lunch at a restaurant off the highway, it was impossible not to notice the hostile glares of many of the men dining there alone. They were deaf and blind to the world until we entered; once they saw us, all they could do was glare over their coffee cups and from under the brims of their hats. No one said anything to us ... We did our best not to be bothered. We didn't hold hands, we didn't touch, but we kept our eyes focused exclusively on each other as we ate our lunch and drank our coffee. (pp. 224-225)

Elsewhere, Helen talks of feeling 'exposed' each time she and 'Isaac' are in the midst of white people. She further observes:

I noticed that the man next to Isaac and the woman standing closest to me were staring at us, and of course they were not alone. I kept my head up without looking at anyone long enough to read their expressions. I knew what was there - anger, pity, contempt. (p. 237)

It might make sense to see the novel not just as about displacement and loss, but also as inscribing the inferiorisation of the migrant Other, and about the ways in which African émigrés become racially traumatised by their host societies. As already pointed out, this is mostly reflected in the American chapters narrated by Helen. In one of the perceptive analyses of the anxieties of race, 'Isaac' has this to say when he is told to 'behave' before white people throughout his stay in America:

Later that evening, [Henry] gave me advice about how to live in America. He told me not to stare at white people, to say 'sir' 
if I was stopped by the police, and to live as quietly as possible. 'This is a hard part of the country to have come to', he said. 'You might wish you hadn't.' (p. 177)

Henry's observations here reflect what Grace Musila calls 'a Euro-American gaze deeply invested in the stereotypical fantasy of people of colour' (2015:120). Following her reading of Edward Said, AbdulRazak JanMahomed, Frantz Fanon and Jean-Paul Sartre, Musila argues that this long-drawn gaze 'was conceptualized within a well-developed portrait of the Orient - and by extension, Africa - legitimized by an assumed knowledge that inscribed the West as the "Seeing Eye"' (2015:120). In Musila's (2015) view:

This assumed knowledge, based on difference, resulted in highly polarized identities. Africa came to be defined as a negation of the West: it was everything Europe was not. Where Europe was mature, civilized and rational, Africa was seen as child-like, irrational and depraved. This definition by negation suggests a process of self-construction based on the definition of the 'Other' as different, which underscores Europe's assumed superiority as one that is concretized by the denigration of other races.... Underpinning this was the assumption that the Other - in this case the African - was incapable of returning the gaze. (p. 120)

Henry's choice of words thus provides an interesting grammar for the 'Euro-American gaze' of the Other that Musila talks about. The ideology behind the 'advice' is that as a black person, 'Isaac' must graciously and quietly oblige whenever he is subjected to any form of suspicion by white people. The use of the phrase 'not to stare at white people' is a subtle reminder of the fact that as a black person he must not 'return the gaze' because black people and white people do not share the same social standing. Thus, though there is no doubt that the 'advice' is aimed at helping 'Isaac' adapt to his new environment, Henry's tips confirm the institutionalisation and normalisation of racism in aspects of American life. This is what Suzette Speight also means when she speaks of systemic racism as being endemic in America, and that 'through its hegemony, the dominant group denigrates, ignores, discounts, misrepresents, or eradicates the target group's culture, language, and history' (2007:130). It is, perhaps, this 'fixed concept' of black people that 'Isaac' resists in the novel. His actions can thus be explained in words that are reminiscent of Mahatma Ghandi's concept of non-violent resistance. For example, when a waitress wants to know if 'Isaac' and Helen would like to take their food with them, the former politely yet determinedly tells her: 'No. We would rather eat here' (p. 37). Later, when Helen begs him that they leave after she becomes increasingly aware of the glares they are receiving from the white patrons in the restaurant, he firmly tells her: "'I am not going to run. I am going to eat my lunch" [here]' (p. 38). What gives All Our Names more resonance, then, is 'Isaac's' and Helen's awareness of the fact that white Americans cannot tolerate the sight of them together, which is an implicit acknowledgement of

3.This recalls Iris Marion Young's typology of 'faces of oppression' here: 'exploitation, 'marginalization' 'powerlessness,' 'cultural imperialism' and 'systemic violence' (1990:48-63). The fact that Henry is specific about how 'Isaac' must conduct himself before the white man shows that the 'advice' he is offering his guest is cultural and structural in orientation. In a way, then, racism is here presented as being systemic. structural in orientation. In a way,
It also reflects white hegemony. 'internalized racism'. ${ }^{4}$ As protagonist-narrators, 'Isaac' and Helen are thus central in the novel's complex engagement with issues of identity and race relations.

There are other ways of understanding how 'Isaac' and Helen navigate America's racial templates in All Our Names. One of these ways is through use of the bird metaphor. The novel's last American chapter appears to revert to the journey motif that started the story of the novel..$^{5}$ But unlike in the first chapter where we encountered 'Isaac' leaving his natal home for Uganda, the penultimate chapter seems to suggest an inclination towards going nowhere. Helen addresses this through a question where she wants to know why immigrants and cross-racial couples should 'leave America when there is so much to see here' (p. 241). Her question spotlights the importance of claiming one's space and, in particular, learning to face one's fears, without walking away from them. The chapter ends with Helen and 'Isaac' 'taking off ... finally becoming ungrounded' (p. 244), supposedly from the racist slurs. Helen's description here would seem to suggest not walking away but being a step ahead of racist templates, literally 'above' and beyond its psychosocial effects.

A powerful image that Mengestu uses, especially in reference to 'Isaac' and Helen's resistance towards race politics in America, is that of a penguin. Penguins have been referenced in literature as symbols of someone who is indomitable, or one who takes on the challenges of living in harsh conditions. Mengestu's novel ends with the penguin imagery. As already said, when 'Isaac' arrives in America's Midwest, he discovers that the society there still frowns on cross-racial couples. Mengestu's idea of juxtaposing 'Isaac' and Helen side by side so that the two of them can 'make a penguin' (p. 152), reinforces his interest in the idea of how people living on the margins of society strive to reinvent themselves so that they can survive conditions and environments that are largely hostile to them. The union between the two - the bird of the air ('Isaac') and the penguin in the water (Helen) - has implications for the definition of the new émigré, compelling us to shift from the drifter character we all along associated 'Isaac' with to the more proactive and resistant penguin. Mengestu could thus be said to place his narrative within a recognisable canon that gestures towards how anxieties of race can be overcome in societies that persistently refuse to integrate.

\section{Conclusion}

In All Our Names, Mengestu weaves a narrative that represents feelings of foreignness and Otherness, in Homi Bhabha's interpretation of the term, experienced by migrant and/or displaced identities and their struggles to reinvent and reaffirm their fluid selves. He gives readers a sociohistorical novel which conflates the factual and the fictional

4.David Williams and Ruth Williams-Morris $(2000)$ define internalised racism as 'the acceptance, by marginalized racial populations, of the negative societal beliefs and stereotypes a mout themselves' and that 'it is premised on the assumption that in stereotypes about themselves and that it is premised on the assumption that in colour-conscious racially stratified society, inferior would be to accept as true the dominant society's ideology of their
inferiority' (p. 255).

5.This is a central conceit in Mengestu's fiction. In How to Read the Air, for example, the road trip undertaken by Jonas connects the reader back to the first chapter of the book which begins with his parents setting out on a long journey from Peoria to Nashville. 
into each other, and which depicts the social and political crises of Ethiopian and Ugandan histories that have driven many of its sons and daughters out of Africa. Mengestu thus creatively engages the levels of ambivalence, of shifting identities and transnationalism, and of the violence, abjection and trauma that confront migrants when they are away from their filial homes.

\section{Acknowledgements}

This work is based on the research supported wholly by the A.W. Mellon Foundation Fellowship. The fellowship holder acknowledges that opinions, findings and conclusions expressed in this article are those of the author, and that the A.W. Mellon Foundation accepts no liability whatsoever in this regard. He also thanks Dr Lynda Gichanda Spencer, project owner and principal coordinator of the Urban Connections in African Popular Imaginaries, under whose mentorship he produced this study.

\section{Competing interests}

The author declares that he has no financial or personal relationships that may have inappropriately influenced him in writing this article.

\section{Author's contributions}

I declare that I am the sole author of this research article.

\section{Ethical consideration}

This article was written purely as an academic discourse on Dinaw Mengestu's creative fiction. No prior permission was obtained from the author.

\section{Funding}

The author wrote this article while he was a postdoctoral fellow at Rhodes University for the Urban Connections in
African Popular Imaginaries (UCAPI) funded by the A.W. Mellon Foundation Fellowship.

\section{Data availability statement}

Data sharing is not applicable to this article as no new data were created or analysed in this study.

\section{Disclaimer}

The views and opinions expressed in this article are those of the author and do not necessarily reflect the official policy or position of any affiliated agency of the authors.

\section{References}

Bhabha, H.K., [1994] 2004, The location of culture, Routledge Classics, London.

Brown, J., 2014, 'All Our Names' tells story of war, love and identity across two continents', viewed 03 May 2019, from https://www.pbs.org/newshour/show/ dinaw-mengestu-new-novel-names.

Foden, G., 2014, 'All Our Names review - Dinaw Mengestu's drama of displacement' The Guardian, viewed 03 May 2019, from https://www.theguardian.com/ books/2014/jun/04/all-our-names-review-dinaw-mengestu-foden.

Herrscher, W., 1986, 'Names in Donald Barthelme's short stories', Names 34(2), 125-133. https://doi.org/10.1179/nam.1986.34.2.125

Hirsch, M., 1996, 'Past lives: Postmemories in exile', Poetics Today 17(4), 659-686. https://doi.org/10.2307/1773218

Mengestu, D., 2007, The beautiful things that heaven bears, Riverhead Books, New York, NY.

Mengestu, D., 2014, All our names, Alfred A. Knopf, New York.

Musila, G.A., 2015, A death retold in truth and rumour: Kenya, Britain and the Julie Ward murder, James Currey, Suffolk.

Paulick, J., 2014, 'Dinaw Mengestu: "Immigrant is a very political term"', Deutsche Welle, viewed 03 May 2019, from https://www.dw.com/en/dinaw-mengestuimmigrant-is-a-very-political-term/a-17921813.

Sacks, S., 2015, 'The rise of the nameless narrator', The New Yorker, viewed 03 May 2019, from https://www.newyorker.com/books/page-turner/the-rise-of-thenameless-narrator.

Speight, S.L., 2007, 'Internalized racism: One more piece of the puzzle', The Counseling Psychologist 35(1), 126-134. https://doi.org/10.1177/0011000006295119

Varvogli, A., 2012, Travel and dislocation in contemporary American fiction, Routledge, New York.

Williams, D.R. \& Williams-Morris, R., 2000, 'Racism and mental health: The African American experience', Ethnicity \& Health 5(3/4), 243-268. https://doi. org/10.1080/713667453

Young, I.M., 1990, Justice and politics of difference, Princeton University Press, Princeton, NJ. 